\title{
Resource degradation, marginalization, and poverty in small-scale fisheries: threats to social-ecological resilience in India and Brazil
}

\author{
Prateep K. Nayak $^{1}$, Luiz E. Oliveira ${ }^{2}$ and Fikret Berkes $^{2}$
}

\begin{abstract}
In this study we examine poverty in local fisheries using a social-ecological resilience lens. In assessing why "fishery may rhyme with poverty", Christophe Béné suggests a typology of impoverishment processes, which includes economic exclusion, social marginalization, class exploitation, and political disempowerment as key mechanisms that accelerate poverty. We extend his analysis by exploring these four mechanisms further and by intertwining them with processes of environmental change and degradation. Our goal is to understand poverty in local fisheries as a process rooted in social and institutional factors as influenced by ecological dynamics. We argue that understanding poverty will require a focus on the social-ecological system (SES) as a whole, and addressing poverty will mean rebuilding not only collapsed stocks but the entire social-ecological system, including restoring relationships between resources and people. Information from two cases, the Chilika Lagoon on the Bay of Bengal in India, and the Paraty region on the southeastern coast of Brazil, is used to understand how fishery social-ecological systems come under pressure from drivers at multiple levels, resulting in a range of impacts and pushing the system to a breaking point or collapse. We analyze elements of what it takes for the whole system to break down or collapse and push fishers into poverty and marginalization. The Chilika SES has already broken down, and the Paraty SES is under pressure from multiple drivers of change. The two cases help contrast key dynamics in the social, cultural, economic, political, and environmental spheres, for lessons on system collapse and recovery. Rebuilding fisheries may be examined as a process of building and strengthening resilience. The challenge is to make the fishery social-ecological system more resilient, with more flexibility and options, not only within fishing activities but also within a range of other sectors.
\end{abstract}

Key Words: Brazil; degradation; disempowerment; exclusion; exploitation; fisheries; human-environment disconnect; identity; impoverishment; India; marginalization; poverty; resilience; small-scale fishery; social-ecological system

\section{INTRODUCTION}

In this study, we contribute to the growing body of research on the importance of examining the origins and dynamics of poverty and impoverishment processes within small-scale fisheries (Allison and Horemans 2006, Béné et al. 2007, Béné and Friend 2011). An overwhelming majority of the world's fisheries are small-scale and small-scale fisheries sustain the livelihoods of about 200 million people worldwide, approximately 95 percent of fishers globally (McGoodwin 2001). This makes them an important focus for poverty research (Béné 2003). Indeed, smallscale fisheries are often defined by their association with poverty, marginalization, vulnerability, exclusion, exploitation, discrimination, and impoverishment processes that play out in different forms and combinations in this specific fishery context (Adger et al. 2005, DFID 2005, Allison and Horemans 2006, Nayak and Berkes 2010, Béné and Friend 2011). Thus, the nature of poverty and its dynamics within a particular small-scale fishery is important both for understanding and assessing that fishery and for understanding poverty more generally.

Existing approaches to measuring poverty are diverse. Some are characterized by an assemblage of monetary and economic methods (Ravallion 1998, Laderchi 2000, Sachs 2005) and others use concepts such as access, entitlements, capabilities, and freedom to bring an institutional and political orientation to poverty (Sen 1981, 1999, Mearns 1996, Leach et al. 1999). A number of frameworks are used in the literature, including sustainable livelihoods (Chambers and Conway 1992, Scoones 1998, Bebbington 1999), vulnerability (Blaikie 1994, Adger et al. 2005, Allison and Horemans 2006, Marschke and Berkes 2006), social well-being (White and Ellison 2007, McGregor 2008,
Bavinck 2009, Coulthard 2009, Trimble and Johnson 2013, Weeratunge et al. 2013) and field-based, bottom-up and participatory tools to deal with social exclusion (Narayan et al. 2000a, 2000b, Beck and Nesmith 2001, Laderchi et al. 2003).

These approaches and concepts illustrate the multidimensional nature of poverty, but they rarely include significant attention to the role of ecological conditions, despite evidence that poverty, socio-institutional processes and environmental degradation are linked in complex, interactive ways. As Barrett et al. (2011:13907) point out:

\begin{abstract}
The persistence of extreme poverty and continued rapid loss of biodiversity appear intimately related. Extreme poverty and biodiversity hot spots are geographically coincident, concentrated in rural areas where livelihoods depend disproportionately on natural capital embodied in forests, rangelands, soils, water, and wildlife...Despite the importance of this coevolutionary relationship, connections between poverty traps and biodiversity conservation remain remarkably underexplored, not only in formal theorizing but especially empirically.
\end{abstract}

The biological dimensions of poverty have not been neglected in fisheries research. Indeed, the conventional wisdom on poverty in fisheries holds that poverty in fisheries, including its origin, factors, and processes, is related to the low level of the natural resources resulting from overexploitation (Gordon 1954, Copes 1989). Christophe Béné is an influential scholar who has dealt with this aspect of poverty, especially the overemphasis on resource supply as a deterministic factor. Béné (2006) has further questioned the two-way link or the environment-poverty nexus, 
whereby poverty is seen as a cause of fish stock exploitation and fish stock depletion as contributing to deeper poverty. He points out that, because of various factors such as inadequate services, low levels of education, politically poorly organized communities and vulnerability, the multidimensional nature of poverty in fishing communities is now universally recognized and accepted. Poverty in fishery-dependent communities is therefore not necessarily directly or solely related to the resource or catch levels (Béné et al. 2007).

Despite the work of Béné and others, a review of key sources shows that there is a very limited literature on social-ecological systems and resilience that has sought to address the problem of poverty, in general, and poverty in small-scale fisheries, in particular. For example, Ecology and Society has published 43 articles since 1997 where the word poverty appeared in the title, in the list of keywords, or in the text. However, none of these articles seem to have used a social-ecological resilience approach to address poverty; a search for the words "social-ecological system" in these articles returned zero results. Similarly, out of a total of 78 special features published between 1997-2014 in Ecology and Society, not a single issue focused explicitly on poverty, let alone poverty's connection with social-ecological systems and resilience in fisheries. We found similar results in the case of the journal World Development: out of a total of 2974 articles on poverty, 274 articles included words starting with "fish", but not a single one of them had any explicit reference to social-ecological systems or resilience. The absence of socialecological system references to poverty is also noted in major global development reports focusing on the issue of poverty. For example, in the four World Development Reports (1978, 1980, 1990 and 2001) that particularly focused on the theme of poverty, the keyword "social-ecological systems" is completely absent and words starting with "fish" appear only 14 times. Similarly, in the three Human Development Reports (1997, 2003 and 2006), known for their clear focus on poverty, there is a conspicuous absence of any reference to "social-ecological systems", even though words starting with "fish" appear 67 times. Thus, there is a need to advance the study of poverty in small-scale fisheries using a socialecological systems approach.

Rejecting the idea that poverty in fisheries is mainly related to the resource supply and exploitation levels as the "old paradigm", Béné (2003) proposed a new framework of socio-institutional mechanisms useful for defining poverty in the context of smallscale fisheries that included economic exclusion, social marginalization, class exploitation, and political disempowerment as the defining factors of impoverishment processes. He argued:

The fact that despite the indisputable existence of cases where community poverty is induced by, or directly related to the overexploitation or depletion of the resource, focus on the biological dimensions of the issue (overexploitation of the resource) has contributed to overlooking other elements which call for a wider analysis of poverty in fisheries, in particular the institutional dynamics of this poverty (Béné 2003:950).

Based on theoretical principles of political economy and political ecology, this framework is an important step forward in bringing attention to the political (power dynamics), economic, social, and cultural resources and constraints associated with poverty.
However, the idea that ecological (natural, biological, environmental) factors can and do have a role in shaping poverty deserves another look using a social-ecological systems approach. After all, poverty never results from the lack of one thing but from many interlinked factors that make it multidimensional (Narayan et al. 2000b, Béné et al. 2007). Without attention to the ecological dimension, the socioinstitutional framework may help to move beyond one kind of overemphasis (biological dimensions of poverty) only to replace it with another (social and institutional mechanisms influencing poverty). A combination of social-institutional-ecological dimensions can offer a more complete understanding of the factors and processes leading to the emergence and continuation of poverty. Hence, our objective is to address the neglect of social-ecological systems thinking with particular reference to poverty in small-scale fisheries. We address the gap in the socialecological systems literature by using one of the socioinstitutional-political typologies devised to understand poverty (Béné 2003, Laderchi et al. 2003) and by showing how adding processes of environmental change can lead to a better understanding of poverty dynamics.

We take Béné's (2003) framework and expand on it to make sense of two small-scale fisheries case studies in India and Brazil where there is evidence of increased marginalization, vulnerability, and poverty. We show how doing this requires the addition of environmental change, social-ecological marginalization, loss of identity, and human-environment disconnection as additional components in the typology of factors (Béné 2003) leading to poverty and impoverishment processes in small-scale fishery systems. Our approach is consistent with Béné et al.'s (2011) work on social-ecological system and resilience thinking in the poverty context of West African small-scale fisheries. Our overall goal is to understand poverty in small-scale fisheries as a process rooted, not only in social, political, and institutional factors as usually defined or in ecological, biophysical, and environmental dynamics alone, but in interactions among these processes. We show that such an understanding of poverty requires a focus on social-ecological systems, that is, integrated complex systems that include social (human) and ecological (biophysical) subsystems in a two-way feedback relationship (Berkes and Folke 1998, Berkes 2011).

\section{Poverty in a social-ecological system context}

Social-ecological systems are complex, integrated systems that imply an integrated concept of humans in nature (Berkes and Folke 1998), an approach that is commonly used in much of the resilience literature (Berkes et al. 2003, Walker et al. 2004). Analysis of social-ecological systems generally differs from analysis of the social or ecological subsystems alone (Ludwig et al. 2001, Liu et al. 2007). In social-ecological systems analysis, human actions affect biophysical systems, biophysical factors affect human well-being and humans in turn respond to these factors (Berkes 2011). Thus, comprehending the social/human dimensions of poverty is as important as understanding resource and ecosystem dynamics. This implies that both social and ecological processes define and shape the patterns and dynamics of poverty in social-ecological systems where social outcomes (e.g., socio-institutional processes) remain contingent upon ecological dynamics (e.g., biophysical and environmental processes) and vice versa (Folke et al. 2005). 
A growing body of literature supports the idea that small-scale fisheries can be understood as integrated social-ecological systems (Ommer et al. 2007, 2011, Mahon et al. 2008, Béné et al. 2011, Nayak 2014). Changes in the social and economic aspects of these fisheries can also be seen as clearly linked to their ecological and political counterparts. Therefore, we require approaches that deal with issues of poverty and marginalization, not just in the social context of these fisheries, but also in the ecological, economic, and political arenas that consider the impact of environmental resources (or lack of them) and multiple power structures that affect people and their well-being. Use of a social-ecological perspective along with other complementary approaches will help to bring together key issues and components of poverty under one umbrella and, thus, allow us to develop a more inclusive understanding. This perspective is also essential if we are to fully understand both the dynamics of ecological degradation and overfishing and identify workable strategies for rebuilding fisheries that include attention to the need to address poverty, marginalization, and the broader question of rebuilding for whom (Khan and Neis 2010).

In small-scale fisheries, increased disparities in wealth and poverty are the meeting place of many interconnected and complex dynamics that stem from social, economic, political, institutional, and ecological structures and processes. The sources of poverty and socioeconomic disparities (drivers) cut across the boundaries between these structures and processes, further operating across scales. Applying social-ecological systems thinking to these problems helps us see the various component parts that combine and intersect to amplify poverty in small-scale fishery systems. These component parts can be understood or characterized in multiple ways, often using combinations of such factors as inputs (investment, technology, fuel oil consumption, gear type), outputs (production, employment, income, impacts), structures (market, management, fishing unit), functions (processing of catch, management), norms/rules (knowledge, ownership, fishing location, and duration/seasonality) and processes (spatial, temporal, rate of modernization) (Kurien 1996, Berkes et al. 2001, Johnson et al. 2005, Johnson 2006). These factors indicate poverty's multiple dimensions: economic, social, political, ecological, and cultural.

Poverty takes place within the context of a social-ecological system that affects humans as much as it affects the environment. Analyses of coastal lagoon small-scale fisheries have documented the relationship between poverty and disruptions in the connections between fishers and their natural environments (Nayak 2011, Nayak and Berkes 2012). Sustainability science captures this as an interaction between people and their environment (Kates et al. 2001) and MEA (2005) considers it as a relationship between ecosystem services and human well-being. Another way to think of this is as cycles of human-environment connections and disconnections that are crucial to understanding poverty and broader disempowerment processes in societies that are primarily dependent on natural resources for survival. Attention to human-environment disconnections signified, in extreme cases, by loss of access to fishery resources and actual displacement from coastal areas caused by a range of factors can help us understand the vulnerability of particular groups to poverty. Conversely, strategies to reconnect them might be one way to help alleviate poverty and equitably rebuild fisheries. We will elaborate on how human-environment disconnection is a key indicator of the prevalence and negative consequences of poverty. Human-environment disconnection may also have serious implications for individual and community identity and future empowerment options (Hapke and Ayyankeril 2004, Neis et al. 2005).

Resilience is defined as the capacity of a system to absorb disturbance and reorganize while undergoing change so as to still retain essentially the same function, structure, identity, and feedbacks (Walker et al. 2004). As an emergent property of socialecological systems, resilience characterizes a system's ability to deal with change (Gunderson and Holling 2002, Hanazaki et al. 2013). Resilience is an essential concept for understanding poverty in small-scale fishery systems because of their vulnerability to successive social and environmental changes and to the loss of system capacity to deal with such changes. In our analysis, we focus particularly on livelihood resilience (Marschke and Berkes 2006) and political and institutional resilience (Adger 2000, Steinberg 2009), which are associated with conditions of empowerment with regard to access, decision-making and institutions.

The social-ecological system resilience approach has some shortcomings, including lack of sufficient attention to power dynamics (Davidson 2010). This shortcoming can, in part, be addressed by using insights from political ecology that offer a way to analyze reciprocal relationships between social, economic, and political inequities and the environment. The humanenvironment angle on poverty connects well with political ecology, which addresses the central questions about relations between human societies, viewed in their bio-cultural-political complexity and recognizing that humans have significantly impacted nature. Two major theoretical thrusts guide political ecological analyses: (1) political economy, with its insistence on the need to link the distribution of power with productive activity, and (2) ecological analysis, with its broader vision of bioenvironmental relationships (Greenberg and Park 1994). Thus, from the perspective of political ecology, the kind of poverty under analysis may range from the largely cultural through the intensely political to the fairly significantly natural (Lowe 2000, Zerner 2000). Neumann (2005) identifies environmental problems as simultaneously political and ecological, social, and biophysical. In relation to poverty's connection to environment, Neumann's observations offer a broad range of challenges for defining poverty. The notion of a two-way interaction and cross-influence of the "social-political" with the "ecological-environmental" is a useful approach to understand critical issues in the emergence and continuation of poverty and its associated processes of disempowerment and marginalization. More importantly, it helps emphasize the need to understand the complex social and political influences of environmental problems, especially from the point of view of local people, marginal groups, and vulnerable populations (Forsyth 2003, Robbins 2004, Nayak and Berkes 2010).

We examine poverty in small-scale fisheries using a lens that combines insights from social-ecological resilience and political ecology. We present two cases using the Béné (2003) typology of (1) economic exclusion, (2) social marginalization, (3) class exploitation, and (4) political disempowerment as a guide. The 
case studies show that in these cases the four socio-institutional mechanisms of poverty are directly linked to social-ecological processes in a two-way feedback relationship, whereby socioinstitutional dynamics influence social-ecological complexities and are also impacted by them. Some of these internal dynamics play a role in defining the nature of poverty in small-scale fishery systems and in framing options for poverty reduction.

\section{RESULTS}

\section{Poverty, degradation, and rebuilding in India and Brazil: two case studies}

\section{Case study I - Chilika lagoon}

Chilika lagoon, on the eastern coast of India, possesses a unique combination of biological and human systems. Its 225 species of fish, 800 species of other fauna, 710 species of plant flora, and a variety of algae and other forms of life characterize the lagoon ecosystem. More than 400,000 caste-based fishers in approximately 150 villages comprise the active human system of the lagoon. These fishers have customarily worked in Chilika's productive ecosystem for cultural and livelihood needs, creating and sustaining a functional human-environment system for generations (more details in Nayak 2011).

Qualitative and participatory research in Chilika was undertaken in two main phases. The first phase of the research took place in 2007-2009 and the data come from household surveys, householdlevel livelihood monitoring, and a general village survey in all fisher villages. Main methods included semi-structured interviews and focus groups with various stakeholders at the community, NGO, fisher federation, and government department levels. Community consultations and workshops were organized to substantiate findings. The second phase of research started in 2011 and sought to assess new developments and recent changes in the social-ecological system. Selected information from this ongoing study also informs parts of this article.

This system experienced a major shock in 2001 when an artificial breach was created to establish a functional sea opening into the Bay of Bengal, a techno-engineering solution designed to mitigate the increasing siltation problem. The intervention resulted in dramatic changes in the ecosystem that were expressed through an increase in the variability, uncertainty, and unpredictability in the lagoon social-ecological system (Nayak and Berkes 2010). While the sea mouth became an instant driver of change, its effects were multiplied by the persistent influence of tiger shrimp aquaculture (Penaeus monodon), which was developed in response to global trends that had turned these creatures of relatively little value into "pink gold" (Kurien 1992). Since the early 1980s, shrimp aquaculture has had impacts through large-scale encroachment into customary fishing areas, loss of fishers' access and entitlements, erosion of local fishery institutions, and habitat impairment (Nayak 2011). The case may be analyzed using Béné's (2003) typology.

\section{(1) Economic exclusion}

Two layers of economic exclusion have resulted from these changes. First, some 60 percent of the lagoon fishing area had been converted into aquaculture farms by 2012, mainly by nonfishers, resulting in the exclusion of customary fishers from substantial parts of their fishing grounds and the consequent denial to them of the opportunity to engage in fishing as an economic activity. Shrimp aquaculture is capital intensive and customary fishers generally lack the capital to invest in this new activity. As a result, over 94 percent of those engaged in shrimp aquaculture in Chilika are members of nonfisher groups (Nayak 2011). In this context, fishing households with assets and financial capital took up intensification, extensification, and diversification of their fisheries activities as alternate livelihood strategies, adding to the problems of poorer households by degrading fishery resources. Consequently, poorer fisher households have either opted for coping strategies (loans, mortgage, asset liquidation, changing food habits, etc.) or labor migration in their search for alternate livelihoods. Ninety-two percent of fishers who chose long-term or seasonal migration happened to be poor (Nayak 2011).

\section{(2) Social marginalization}

Chilika society is largely stratified, based on the Hindu caste system. It comprises a number of higher castes (e.g., Brahmins, Karans, Khandayats, and Khetriyas) who are typically nonfishers and several caste-based groups of customary fishers, including seven castes and their five subcastes. The fishers are generally considered lower caste; many of them have the status of a Scheduled Caste as per the constitution of India. Thus, the customary fishers are on the lower rungs of the inter-caste system, which has historically marginalized them within Chilika society. Inter- (between nonfishers and fishers) and intra- (within the fisher castes and their subcastes) caste processes rigidly maintain the status quo by discriminating against the caste-based fishers, denying access to resources. Nonfishers control most of the lagoon resources through lucrative shrimp aquaculture, whereas the caste-based fishers remain subject to barriers as a result of economic marginalization ultimately based on social criteria of caste. The fishers of Chilika are further subdivided into five main castes and a number of subcastes. Those who are at the bottom of the intra-caste hierarchy tend to be discriminated against by others in the same caste through local rules on fishing gears, methods and techniques, fishing locations, and seasons and the types of species they catch and the size of their catches, all of which favor the higher ups in the caste hierarchy and further marginalize those who are at the bottom (see Nayak 2011 for details).

\section{(3) Class exploitation}

With shrimp market globalization, the existing combinations of class and caste dynamics, along with other changes in Chilika, have exacerbated marginalization. Class exploitation takes the form of the upper (management) class extracting surplus labor and surplus wealth from a (lower) working class using a system of patron-client relationships. Each fisher household is attached to one or more fish traders through a verbal agreement and receives interest-free advances in exchange for committing to sell their daily product to the same trader. Close to 90 percent of households in the two study villages have held such cash advances. Despite being interest-free, there are always strings attached to these advances, whereby fishers not only stay obliged to sell to the one trader, but also have to compromise on weight and price in addition to paying a commission to the trader. This amounts to an active process of economic exploitation of the fishers who are already dealing with poverty and marginalization. The negative fallout of this is also felt at the level of fishers' political and social 
lives, because they remain virtually voiceless before the economic strength of the traders. Fishers who end up indebted due to a livelihood crisis can be described as being trapped in the equivalent of a "bonded labor" situation (Nayak and Berkes 2011), making them vulnerable to hyper-exploitation. The situation is even worse for fishers who end up interacting with rich moneylenders: 98 percent of fisher households in two study villages took cash loans from these moneylenders as a coping strategy and had to pay interest rates ranging between 60-120 percent per annum (Nayak 2011). The ratio between household incomes and the size of the loans suggests that the economicallypoor fisher families will continue to be trapped in a vicious cycle of indebtedness.

\section{(4) Political disempowerment}

Political and bureaucratic representation of fishers is an important aspect of caste and class politics in Chilika and nonfishers have been at the helm of decision-making because of their continuous electoral success, while the fishers remain underrepresented in the formal political system. Political disempowerment also results from unfavorable fishery policies that restrict fishers' access and entitlement and promote frequent caste and class conflicts. Political disempowerment in Chilika is exacerbated by exclusion, marginalization, and exploitation processes. Fish represented "power" for fishers and as the fish have disappeared so has their power. There is growing involvement of higher caste and class elites from political and bureaucratic circles in shrimp aquaculture. This has pushed the customary fishers into a state of extreme powerlessness. The higher castes and other elite classes in the lagoon have expanded their financial capital through large profits. Fishers have an ever-dwindling role in decision-making. Encroachments on fishing areas and growing caste conflicts have shaped the nature of politics around lagoon resources. Nonfishers command money, muscle, and political power and have been using these to displace fishers from their fishing areas and livelihoods as well as from decision-making.

\section{Case study II - Paraty}

Paraty, on the southeastern coast of Brazil, is a municipality located inside the remnants of the Atlantic Forest, one of the world's hotspots for biodiversity conservation (Metzger 2009). The beautiful coastal landscapes also make the region attractive for tourism. In Paraty, most of the people (population over 37,500 people, see IBGE 2013) live in some 22 villages along the coast or on islands. Historically, people living in Paraty engaged in a mixed economy that involved small-scale fishing, small-scale agriculture, hunting, and gathering. Recently, especially after the construction of a coastal highway (BR-101) in the area during the 1970s, there has been a growing demand for tourism services as well.

Data presented for Paraty comes from two primary studies conducted by one of the authors. The first, published in Oliveira (2010), was a research project in which 206 semi-structured interviews were conducted with small-scale fishers about their livelihoods, fisheries, and other economic and ecological aspects of their lives. The second study was carried out as part of Oliveira's doctoral fieldwork conducted between September 2010 and October 2011 in Tarituba, a community in Paraty. In this latter study, a qualitative approach was used to assess how community members perceived social-ecological changes and some of the key impacts of such changes. In total, 36 unstructured interviews were conducted and the collected data were analyzed according to major categories of perceived changes and their causes.

Hanazaki et al. (2013) showed that fishing is the single most important resource activity in the area. The most important commercial species are snook (Centropomus spp.), seabob shrimp (Xiphopenaeus kroyeri), mackerel (Scomberomurus cavalla) and grouper (Epinephelus spp.) (Begossi et al. 2010). Three main processes have contributed to the poverty of the small-scale fishers: (1) a biodiversity conservation discourse that has led to restrictions on access to territories and resources, (2) land speculation caused by tourism growth, and (3) industrialization of the fisheries. These factors are not ranked; there are overlaps in how they have impacted poverty and marginalization processes in Paraty. We examine these three main processes, using the same framework as we used for Case Study I.

\section{(1) Economic exclusion}

One way of restricting fishers' access to the market economy is by restricting their access to fishing territories and resources. There are at least two of these types of restrictions operating in Paraty. The first is a result of the creation of several marine and coastal protected areas (at least 11 protected areas overlap with the area of Ilha Grande Bay, varying from no-take areas to areas that allow specific resource use) (Oliveira 2010). Although the first protected areas were created in the $1970 \mathrm{~s}$, most small-scale fishers in the area did not know about their existence until they were caught and charged for environmental "crimes" by enforcement agencies (Oliveira 2010). For example, one of the most restrictive protected areas overlapping with the Paraty area is the Estação Ecológica de Tamoios (IUCN category Ia), created in 1990, which comprises 29 islands with a one $\mathrm{km}$ band around each island. Some of those islands were important small-scale fishing spots in the past (Begossi 2010). The second type of restriction is a consequence of competition with industrial fisheries. Most small-scale fishers believe that the industrial fisheries (especially shrimp trawlers and the industrial sardine fisheries) are the main cause of the depletion of fish stocks that they have observed (Oliveira 2010). With higher catches and possible damage to fish stocks and habitats, the industrial fisheries have been steadily encroaching on traditional small-scale fishing areas.

\section{(2) Social marginalization}

The arrival of tourism in Paraty gave rise to land speculation as local dwellers started to sell their properties to tourists or to tourism companies (Adams 2002). These local people then started moving either to the main city or to places farther from the beach, usually poor areas. The migration process is locally known as "subir o morro" ("move up the mountain") and can be seen in many villages in Paraty. Those with no formal tenure over their land have been most affected by this process because the tourism companies undervalued the prices of such properties. Tourism has thus become an economic driver that has led to social marginalization. Another layer of complexity is added by the fact that the properties and houses purchased by the tourism sector are located closer to the beach. As a result, the tourism sector has taken over the beach and the traditional ranchos de pesca (wooden houses built to store fishing equipment), which were common on the beach in the past, are relegated to the margins of the beach, if they are present at all. 


\section{(3) Class exploitation}

Two processes that may lead to class exploitation are the industrialization of fisheries and the asymmetry in economic gains between fishers and fish buyers. In an industrial fishery, the means of production are owned by individuals or groups (companies) who use their control over the means of production to extract wealth from those who are hired as workers. The division of profits in the sardine fisheries is a good example of this asymmetry in access to fisheries-related wealth. As part of the contract, fishers pay the costs of the trip in terms of fuel and ice. Half the fish caught in a given fishing trip belongs to the boat owner. The other half is sold, after expenses, and the remaining amount is shared among the crew. But shares are not evenly distributed: the cook gets 1.5 shares, the helmsman gets three shares and the fishers get one share. In times of poor catches, fishers remain in debt to the boat owner because fishing trip expenses (fuel and ice) are paid by the crew and fishers receive the smallest share of the profits, if any at all (see Moreno et al. 2009 for details). As well, there is unbalanced trade (fish to money) between fishers and fish buyers, with fish markets controlling the prices of fish landed. The unequal relationship between fish market owners/fish buyers and small-scale fishers is usually maintained by informal loans, in which fish buyers give fishers cash in advance for fishing trips expenses (mainly for ice and fuel) and fishers are thereby obligated to sell their catches to this buyer. This obligation is sustained by informal social rules and sanctions that force the fishers to make compromises on price and freedom to sell elsewhere. These practices make the fishers vulnerable and prone to class exploitation.

\section{(4) Political disempowerment}

The prevailing model of resource management in Brazil is topdown, with centralized decision-making (Begossi et al. 2004). In Paraty, the creation and management of marine and coastal protected areas happen mostly without the participation of resource users, especially small-scale fishers. A survey conducted in 2009 showed that around 30\% of small-scale fishers in Paraty did not know about the existence of marine and coastal protected areas in their region (Oliveira 2010). Fishers, not surprisingly given their lack of involvement, perceive the creation of protected areas as an impediment to their livelihood activities, that is, a source of conflict in the area. One fisher, when asked about the existence of protected areas in the region, said: "Esse meioambiente só pode ser o anticristo", thereby accusing environmental agencies of being "the antichrist" (Oliveira 2010:249). The lack of small-scale fisher participation in management is partially related to low levels of education; more than $80 \%$ of them have less than 10 years of formal education and $26 \%$ are illiterate (Lopes 2010). This adds to their political disempowerment, especially when resource management laws are created by distant authorities in language that is not transparent to fishers.

\section{DISCUSSION}

Towards a social-ecological understanding of poverty in smallscale fisheries

Béné's typology provides the basis for a rich analysis of poverty drivers based on four mechanisms: economic exclusion, social marginalization, class exploitation, and political disempowerment. We have shown that each of these may be influenced by a combination of drivers in the social, ecological, and political arenas, while also contributing to an equally diverse set of impacts, described as the "nature of the discrimination" by Béné (2003:961). We suggest that ecological, economic, social, political, and class-based processes are all likely interrelated in terms of combining in complex sets of social relations, and generally to the advantage of the local elite. That is, they operate through a mutual feedback mechanism, being parts of an interdependent social-ecological system. For example, economic exclusion can accelerate social marginalization and class exploitation can cause political disempowerment, all linked integrally to the ecological processes upon which fisheries depend. This is consistent with the view that social and ecological systems are interdependent and social and institutional dynamics are integral to biophysical and ecological processes (Liu et al. 2007, Christie 2011). Any attempt to separate them is artificial and arbitrary (Berkes and Folke 1998). Thus, we argue that ecological factors are also likely to influence the four processes outlined by Béné (2003).

We see the evidence for this in both the Chilika and the Paraty cases. In Chilika, Béné's four mechanisms operated through changes in the social-ecological system. The main driver of poverty in Chilika seems to be a class/caste-based process of resource capture by local elites; the ecological effect of the opening of the sea mouth appears to have exacerbated an already untenable social situation. The new artificial opening of the lagoon to the sea acted as an immediate driver and led to disturbances in biophysical processes, culminating in serious impacts on the social subsystem. Adverse social, ecological, and political results of shrimp aquaculture joined forces with the impacts of the new sea mouth in a series of cascading effects on the social-ecological system. A process of encroachment on fishing areas by the powerful aquaculture industry triggered economic exclusion. Lagoon ecosystem degradation prompted large-scale loss of fish production that impacted fisher livelihoods. Exclusion from local economic activities resulted in the physical separation of the fishers from the lagoon and many of them migrated to distant cities where they are often sucked into urban poverty. Clearly, economic exclusion in this case has had ecological, social, and political drivers and legacies. Chilika is a glaring example of poverty's connection with social-ecological processes. Here, both of the major drivers (shrimp aquaculture and the artificial sea mouth) had important ecological dimensions that were inherently linked to changes in the social subsystem that contributed to impoverishment.

In Paraty, as in Chilika, the effects of the four mechanisms proposed by Béné (2003) are both less linear and more complex than described by him. For example, both economic exclusion and class exploitation seem to be influenced by the process of industrialization of fisheries. On the one hand, industrialization increased the pressure on resources as the industrial fisheries took over areas used by the small-scale sector, disconnecting smallscale fishers from their resources and customary territories. On the other hand, industrialization created an unbalanced type of employment, whereby former small-scale fishers started working longer hours and sometimes became trapped in a debt relationship with the boat owner. Thus, industrialization of fisheries led to social and ecological changes that increased the poverty of smallscale fishers and concentrated resources in the hands of a few. Biophysical attributes of the coastal Atlantic Forest region paved the way for two other drivers of change. The first was the Atlantic 
Forest conservation discourse and the second was the arrival of the tourism industry. Atlantic Forest conservation accelerated the economic exclusion process through the top-down creation of marine protected areas. The arrival of the tourism industry triggered a process of land speculation, resulting in spatial marginalization of the local people.

\section{Extending the typology of impoverishment processes}

Based on the analysis of both socio-institutional and socialecological factors and their interconnections, the existing impoverishment paradigm may be broadened by including environmental factors. In proposing such an extended typology, we use the environmental context as a non-negotiable element. Politics and power often shape how the environmental context is manipulated within the larger discourse of resource conservation and human development (Robbins 2004). We will discuss environmental change, social-ecological marginalization, loss of identity, and human-environment disconnection as new components in the typology of factors leading to poverty and impoverishment processes in small-scale fishery systems. Starting with the four mechanisms of Béné (2003), we offer four additional mechanisms (Table 1).

\section{Environmental change}

The connection of poverty to the natural environment is real: the nature and intensity of poverty are influenced by changes in the environmental subsystem. Degradation of the natural system becomes synonymous with the occurrence of poverty and its related dimensions such as food insecurity. Our case studies indicate that economic or income poverty is directly linked to the loss of fish productivity and access to resources. The connection between poverty and the resource or natural environment is a common thread in both the Chilika and the Paraty cases. Consequently, adverse changes in the environmental system have a direct impact on the level of poverty in small-scale fishing systems. In marginalized societies, the impacts of environmental changes are likely to be unjust, making resource-dependent groups and, particularly, the poorest members of those groups even more vulnerable. The uneven distribution of impacts has important implications for processes of discrimination and poverty. Actions taken to deal with such impacts also have important justice implications because their benefits and costs are frequently distributed in ways that exacerbate current vulnerabilities rather than reducing them (Adger et al. 2006).

\section{Social-ecological marginalization}

Marginalization cannot be attributed to social factors alone. Bénés conceptualization of marginalization based on social criteria can be expanded to include ecological criteria. Our analysis suggests that discrimination processes in resourcedependent societies either start with environmental as well as social drivers or result in impacts that are social-ecological in nature. Marginalization is not measurable by economic criteria, such as regional production data alone, and average marginalization should not be seen simply as a state of being, but rather as a process of instability and disempowerment over time. Several interrelated elements impact social and economic conditions, political standing, and environmental dynamics (Nayak and Berkes 2010). Such an explanation presents a more complex, multidimensional understanding of marginalization. We propose to extend Béné's (2003) definition of social marginalization to also include an ecological dimension within the broader context of the social-ecological system. Drawing from the literature and informed by our two case studies, we define social-ecological marginalization as a process that leads to loss of control over a resource, service or commodity on the part of certain actors, based on both social and ecological criteria. Combining social and ecological criteria to define and understand poverty supports both the need for greater human-ecological integration in understanding poverty and the idea that poverty is a process.

\section{Loss of identity}

In fisher societies, poverty can be closely linked to individual and community identity (Hapke and Ayyankeril 2004, Neis et al. 2005, Power 2005). Particularly in Chilika, food insecurity and increased poverty are closely associated with community members losing their identities as customary caste-based fishers. Robson and Nayak (2010:275) summarized the situation as follows:

With members leaving fishing and many heading to regional urban centers, a process of cultural change is weakening the traditional notion of a "fisher community", as defined by caste and occupational identity. The pride felt by individuals who belonged to the fisher community has been replaced by a deep sense of alienation, where occupationally displaced fishers do not feel they belong to either world-neither Chilika nor the city where they work.

In addition to cultural identity, we emphasize the political and ecological identity of small-scale fishers since, in both Chilika and Paraty, cultural, political, and ecological identities were strongly linked to one another. For fishers, the presence of fish signifies power such that if there is no fish, there is no power. Hence, rebuilding the fish stocks on which small-scale fisheries depend should be synonymous with rebuilding fishers' identities. Further, rebuilding entire "fish chains" from ocean to plate (Khan and Neis 2010:347) has the potential to rebuild fishers' identities. An improved situation of empowerment and the restoration of fishers' identities will have occurred when the fishery is associated with power as opposed to poverty.

\section{Human-environment disconnect}

A human-environment disconnect may be defined as the destruction of the physical, psychological, economic, and political relationship between people and their environment as well as among each other. This may result from loss of access and tenure rights, loss of livelihoods, out-migration and loss of environmental knowledge and sense of stewardship (Nayak and Berkes 2012). If small-scale fishing environments are integrated social-ecological systems (Ommer et al. 2007, Mahon et al. 2008, Nayak 2014) then the fishers who are intrinsically linked to these systems are social-ecological beings. Connections between the components of the ecological and human subsystems (Nayak 2011) have been characterized as a relationship between ecosystem flows and human well-being (MEA 2005). In Chilika, alienation of the fishers from their lagoon environment was one of the major outcomes of changes. In Paraty, human-environment disconnection has not yet taken place, but is likely to occur if trends continue. We suggest that disconnecting particular human and ecological subsystems adversely impacts the level of social- 
Table 1. Extended typology of factors leading to impoverishment processes and poverty in small-scale fishery social-ecological systems. Source: adopted and modified from Bene (2003).

\begin{tabular}{|c|c|c|c|c|}
\hline $\begin{array}{l}\text { Type of } \\
\text { discrimination }\end{array}$ & Definition & $\begin{array}{l}\text { Type of main driver } \\
\text { and its scale/level }\end{array}$ & $\begin{array}{l}\text { Nature of impoverishment/ } \\
\text { discrimination }\end{array}$ & Nature of main influence/impact \\
\hline $\begin{array}{l}\text { Economic } \\
\text { exclusion }\end{array}$ & $\begin{array}{l}\text { Process which leads to the leaving out from } \\
\text { a particular economic activity of certain } \\
\text { individuals due to their economic/financial } \\
\text { inability to access the factor of production } \\
\text { necessary to enter and/or operate this } \\
\text { activity }\end{array}$ & $\begin{array}{l}\text { Global market } \\
\text { Local and regional } \\
\text { economic and social } \\
\text { structures }\end{array}$ & $\begin{array}{l}\text { Economic, institutional, } \\
\text { social, political, ecological }\end{array}$ & $\begin{array}{l}\text { Economic (livelihoods); } \\
\text { Institutional (decision-making); } \\
\text { Political (disempowerment, } \\
\text { identity); Ecological (human- } \\
\text { environment disconnection); Social } \\
\text { (human-human disconnection) }\end{array}$ \\
\hline $\begin{array}{l}\text { Social } \\
\text { marginalization }\end{array}$ & $\begin{array}{l}\text { Process which leads to the denial of the } \\
\text { command over a resource, service or } \\
\text { commodities for certain actors based on } \\
\text { social criteria such as caste, gender, or } \\
\text { ethnic origin }\end{array}$ & $\begin{array}{l}\text { Local and regional } \\
\text { level social } \\
\text { stratification and } \\
\text { norms }\end{array}$ & $\begin{array}{l}\text { Social, cultural, political, } \\
\text { economic }\end{array}$ & $\begin{array}{l}\text { Social (inequity, injustice, human- } \\
\text { human disconnection); Political } \\
\text { (disempowerment, identity); } \\
\text { Institutional (decision-making) }\end{array}$ \\
\hline Class exploitation & $\begin{array}{l}\text { Situation where a higher class is perceived } \\
\text { as being in the position of extracting } \\
\text { surplus labor from a (lower) working class, } \\
\text { or where this "lower" class is considered as } \\
\text { not receiving its "fair share" in the benefits } \\
\text { created by an economic activity }\end{array}$ & $\begin{array}{l}\text { Global market } \\
\text { Local and regional } \\
\text { economic and social } \\
\text { structure }\end{array}$ & $\begin{array}{l}\text { Economic, social, ecological, } \\
\text { political }\end{array}$ & $\begin{array}{l}\text { Economic (inequity, profit, } \\
\text { occupational displacement); Social } \\
\text { (divisions and rigid stratification); } \\
\text { Ecological (pressure on existing } \\
\text { resource and overexploitation); } \\
\text { Political (identity, emergence of } \\
\text { ruling class, human rights) }\end{array}$ \\
\hline $\begin{array}{l}\text { Political } \\
\text { disempowerment }\end{array}$ & $\begin{array}{l}\text { Situations where actors are "left out" from } \\
\text { participation and/or decision-making } \\
\text { processes leading to low/poor opportunities } \\
\text { to control and govern their own command } \\
\text { over resources. This may result in reduction } \\
\text { or even denying of access and use of the } \\
\text { resources. The initial barriers are due to } \\
\text { asymmetrical power relationships based on } \\
\text { social stratification. }\end{array}$ & $\begin{array}{l}\text { Local, regional, state } \\
\text { and national politics } \\
\text { and power structures }\end{array}$ & $\begin{array}{l}\text { Political, social, ecological, } \\
\text { cultural }\end{array}$ & $\begin{array}{l}\text { Political (disenfranchisement, } \\
\text { disempowerment, identity); } \\
\text { Institutional (decision-making, } \\
\text { political voice and platform); } \\
\text { Cultural (loss of identity); Social } \\
\text { (disintegration and conflicts) }\end{array}$ \\
\hline $\begin{array}{l}\text { Environmental } \\
\text { change }\end{array}$ & $\begin{array}{l}\text { Both known and unexpected changes in the } \\
\text { human-dependent environment and its } \\
\text { associated resources due to direct and } \\
\text { indirect influence of multi-level drivers }\end{array}$ & $\begin{array}{l}\text { Global market and } \\
\text { climate } \\
\text { State and national } \\
\text { policies } \\
\text { Local and regional } \\
\text { management } \\
\text { practices }\end{array}$ & $\begin{array}{l}\text { Ecological, economic, social, } \\
\text { cultural, political }\end{array}$ & $\begin{array}{l}\text { Ecological (resource degradation, } \\
\text { human-environment } \\
\text { disconnection); Economic (decline } \\
\text { in productivity and fisher income); } \\
\text { Cultural (loss of environment as } \\
\text { cultural capital); Political (politics } \\
\text { of conservation and development, } \\
\text { identity, power) }\end{array}$ \\
\hline $\begin{array}{l}\text { Ecological } \\
\text { marginalization }\end{array}$ & $\begin{array}{l}\text { Process which leads to the denial of the } \\
\text { command over a resource, service or } \\
\text { commodities for certain actors based on } \\
\text { ecological criteria such as type of } \\
\text { ecosystem, status of degradation, level of } \\
\text { impact from drivers }\end{array}$ & $\begin{array}{l}\text { Global market and } \\
\text { climate } \\
\text { State and national } \\
\text { policies } \\
\text { Local and regional } \\
\text { management } \\
\text { practices, social } \\
\text { norms and } \\
\text { institutional rules }\end{array}$ & Ecological, political, cultural & $\begin{array}{l}\text { Ecological (environmental justice, } \\
\text { human-environment disconnection, } \\
\text { identity); Social (inequity, injustice, } \\
\text { human-human disconnection); } \\
\text { Political (disempowerment, } \\
\text { identity); Institutional (decision- } \\
\text { making); Cultural (identity) }\end{array}$ \\
\hline Loss of identity & $\begin{array}{l}\text { Fishers' perceptions are context-dependent, } \\
\text { spatially contingent, identity-bound, } \\
\text { gendered, age specific and influenced by the } \\
\text { social and cultural worlds which they } \\
\text { inhabit (Narayan et al. 2000b) }\end{array}$ & $\begin{array}{l}\text { Local, regional, state } \\
\text { and national politics } \\
\text { and power structures } \\
\text { Local and regional } \\
\text { level social } \\
\text { stratification and } \\
\text { norms }\end{array}$ & Cultural, political, ecological & $\begin{array}{l}\text { Social (inequity, injustice, human- } \\
\text { human disconnection); Political } \\
\text { (disempowerment, identity); } \\
\text { Institutional (decision-making); } \\
\text { Cultural (identity) }\end{array}$ \\
\hline $\begin{array}{l}\text { Fishers' } \\
\text { disconnection } \\
\text { from resource and } \\
\text { from other fishers }\end{array}$ & $\begin{array}{l}\text { Destruction of the physical, psychological, } \\
\text { economic, and political relationship of } \\
\text { people with their environment and among } \\
\text { each other, which may result from loss of } \\
\text { access and tenure rights, loss of livelihoods, } \\
\text { out-migration and loss of environmental } \\
\text { knowledge and sense of stewardship (Nayak } \\
\text { and Berkes 2012). }\end{array}$ & $\begin{array}{l}\text { Global, state, and } \\
\text { national market and } \\
\text { governance policies } \\
\text { Decline in local and } \\
\text { regional production } \\
\text { Local and regional } \\
\text { conflicts and } \\
\text { contestations }\end{array}$ & $\begin{array}{l}\text { Ecological, political, } \\
\text { economic, social, cultural }\end{array}$ & $\begin{array}{l}\text { Ecological (human-environment } \\
\text { disconnection); Social (human- } \\
\text { human disconnection); Political } \\
\text { (loss of access, rights, entitlements, } \\
\text { knowledge and ownership) }\end{array}$ \\
\hline
\end{tabular}


ecological system resilience and makes dependent human, and often natural populations as well, more vulnerable. The idea of disconnection is distinct from, but also linked to, economic and ecological marginalization. In an economic sense (as in Chilika), loss of fishing-based livelihoods and subsequent out-migration of the fishers led to their physical disconnection from the lagoon environment. Large-scale adverse changes in the lagoon ecosystem contributed to the vast depreciations in the local economy and became a direct driver for human-environment disconnection in Chilika. Even though at a completely different scale, similar trends in human-environment disconnection are recorded in the case of Paraty. It is perhaps more accurate to think of such disconnects as occupying the extreme end of the marginalization and disempowerment continuum. Collapse of a fishery may be characterized as an extreme state of humanenvironment disconnection and rebuilding a collapsed fishery would mean actively restoring the appropriate connections between the two systems.

Findings in both Chilika and Paraty draw attention to the central role of social-ecological considerations in understanding poverty, in addition to those mechanisms outlined by Béné (2003). Poverty is not a result of socio-institutional processes alone or their specific components. Our case studies suggest that the interactions and dynamics associated with social, institutional, economic, political, and ecological processes determine the extent of poverty. Hence, poverty is as much influenced by socioinstitutional dynamics as it is by ecological and biophysical processes and interactions between them. The situation in both Chilika and Paraty suggests that poverty and all its associated processes largely take place within an integrated social-ecological context in which social outcomes remain contingent upon ecological dynamics and vice versa. A social-ecological perspective recognizes the role of humans in shaping ecosystem processes and dynamics (Dale et al. 2000, Waltner-Toews and Kay 2005). In order to generate a complete understanding of poverty and marginalization, we propose that attention to the "central role of socio-institutional mechanisms in accelerating poverty" (Béné 2003:950) should be supplemented by attention to the central role of social-ecological factors in accelerating poverty as shown in the two case studies.

\section{CONCLUSIONS}

Béné (2003) made a seminal contribution to the literature by showing poverty to be a process, driven by four socio-institutional factors. We extend his argument by pointing out that a more complete definition of poverty would include four other factors informed by a consideration of the integrated, interactive, and co-evolutionary nature of social-ecological systems (Table 1). In Chilika, the process of increasing poverty mainly started with changes in the ecological subsystem (e.g., habitat destruction, water quality and salinity balance, species composition, and food web) and gradually affected the social subsystem through loss of fish productivity, fisher livelihoods, local institutions, and outmigration. In Paraty, economic and political restrictions (e.g., pressure from industrial fishing, denial of access to resources and fishing areas through the establishment of protected areas, and reduced access to housing and beaches through tourism development) paved the way for increased poverty. Here, discrimination processes and poverty first originated in the social subsystem, which subsequently impacted the ecological subsystem when biodiversity conservation became the main focus of management.

Processes of discrimination (Béné 2003) did not start with the crises we describe in the two cases. It is common knowledge that caste-based stratified societies like Chilika and largely classdefined societies like Paraty are associated with discrimination and these preceded the processes described here. In Chilika, fishers on the lower rungs of the caste system had always been allotted some of the most difficult areas to fish and less productive lagoon areas (Nayak and Berkes 2011). Similarly, in Paraty, largescale fishers have historically belonged to a higher economic class because they can afford improved fishing gears and are generally better positioned than small-scale fishers to deal with investment risks and challenges. However, massive changes in livelihoods, institutions, and cultures, along with social, economic, and political practices that operated through the influence of multiple drivers at different scales have extended and deepened the risks and consequences of poverty in these areas. Social-ecological systems start to show signs of collapse when the existing rules, norms, value systems, and terms of interaction between people and with the ecosystem become dysfunctional. This idea of dysfunction is an important part of our argument about poverty and indicates the presence of heightened pressure on the socialecological system in both case study contexts. However, we recognize that the application of this argument is more compelling for Chilika than for Paraty where some livelihood adaptation has limited the increase in poverty (Hanazaki et al. 2013). Drawing from our analysis, we argue nonetheless that we should anticipate a marked intensification in the mechanisms of exploitation, marginalization, exclusion, and disempowerment during times of environmental and social crisis.

Linked to ecological considerations, the political ecology of the two fisheries offers important clues to the understanding of poverty in social-ecological systems. Even though fishers were historically weak in their political and social standing in both contexts, they had still retained some political voice and power that mainly resulted from the earlier recognition of their relationship to the lagoon as customary fishers. However, erosion of the political capital of the fishers was quicker and more complex after the onset of the social-ecological crisis. For example, aquaculture politics and the resulting power imbalance in Chilika led to the loss of sustainable livelihoods (Chambers and Conway 1992), in effect, to a loss of resilience through adverse changes in the livelihoods, institutions, resource access, and decision-making systems of the fishers. Similarly, in Paraty, the creation of marine protected areas and the associated environmentalist discourse created grounds for displacing smallscale fishers from their customary occupation and contributed to the development of a power imbalance and complex politics organized around development versus conservation priorities. We have already emphasized that the loss of political capacity and decision-making power was a culmination of economic exclusion, social marginalization, and class exploitation in both Chilika and Paraty. The fishers' political-economic marginalization was critical to their inability to fend off the imposition of protected areas and the environmentalist discourse just further disempowered them. 
In both cases, the contribution of politics and power dynamics to the creation and persistence of poverty is clear. Political disempowerment also has the potential to make the problems of discrimination and poverty more persistent and perhaps even permanent. It creates a vicious cycle of powerlessness (exclusion, marginalization, exploitation, disempowerment) that is hard to break. Even though political and institutional disempowerment is an important contributor to poverty, the ecological basis of such disempowerment processes should not be overlooked in a social-ecological system analysis. This is consistent with the idea that ecological and institutional factors are intertwined in how poverty and disempowerment processes emerge and continue. In the context of poverty, dealing with the collapse and rebuilding of fisheries can be seen as a process that could potentially create and strengthen social-ecological and political resilience, which will in turn require building more flexibility and options for the fishery.

Just as ecosystem-based management requires consideration of social factors (Berkes 2012), analysis of poverty requires consideration of ecological factors. Addressing poverty will mean rebuilding not only collapsed stocks but the entire socialecological system by restoring the connections between resources and people and shifting power dynamics, as Khan and Neis (2010), Miller et al. (2010) and Nayak and Berkes (2012) all recognize. Rebuilding fisheries, in turn, may be understood as a process of building and strengthening resilience. The challenge is to make the fishery more resilient by creating flexibility and options within a range of sectors and that requires addressing, and perhaps reversing, the various processes that contribute to poverty creation.

Responses to this article can be read online at: http://www.ecologyandsociety.org/issues/responses. $\mathrm{php} / 6656$

\section{Acknowledgments:}

We wish to express our grateful thanks to the special theme editors Barbara Neis and Rosemary Ommer for their comments and suggestions on an earlier draft of this paper. Our special thanks to the fishers in Chilika and Paraty for their unconditional friendship, support, and collaboration during the field research. Nayak's work is supported by the Social Sciences and Humanities Research Council (SSHRC) of Canada, with additional funding provided by the University of Waterloo through the Office of the Provost and the Canada Excellence Research Chair (CERC) in Ecohydrology. Berkes' work has been supported by SSHRC, the Canada Research Chairs program (http://www.chairs-chaires.gc.ca), and by the International Development Research Center (IDRC). Oliveira's work in Paraty has been supported through doctoral scholarships from the IDRC and the National Council for Scientific and Technological Development ( CNPq), Brazil.

\section{LITERATURE CITED}

Adams, C. 2002. Identidade Caiçara: exclusão histórica e sócioambiental. Pages 27-43 in Atualidades em etnobiologia e etnoecologia. Palestras convidadas do IV simpósio Brasileiro de etnobiologia e etnoecologia. Ulysses P. de Albuquerque. Sociedade Brasileira de Etnobiologia e Etnoecologia, Recife, Brazil.

Adger, W. N. 2000. Social and ecological resilience: are they related? Progress in Human Geography 24(3):347-364. http://dx. doi.org/10.1191/030913200701540465

Adger, W. N., T. P. Hughes, C. Folke, S. R. Carpenter, and J. Rockstrom. 2005. Social-ecological resilience to coastal disasters. Science 309:1036-1039. http://dx.doi.org/10.1126/science.1112122

Adger, W. N., J. Paavola, and S. Huq. 2006. Towards justice in adaptation to climate change. Pages 1-19 in W. N. Adger, J. Paavola, S. Huq, and M. J. Mace, editors. Fairness in adaptation to climate change. MIT Press, Cambridge, Massachusetts, USA.

Allison, E. H., and B. Horemans. 2006. Putting the principles of the sustainable livelihoods approach into fisheries development policy and practice. Marine Policy 30:757-766. http://dx.doi. org/10.1016/i.marpol.2006.02.001

Barrett, C. B., A. J. Travis, and P. Dasgupta. 2011. On biodiversity conservation and poverty traps. Proceedings of the National Academy of Sciences 108:13907-13912. http://dx.doi.org/10.1073/ pnas. 1011521108

Bavinck, M. 2009. Interactive governance and the wellbeing of the coastal poor. ESPA workshop 1 on building capacity for sustainable governance in South Asian fisheries: poverty, wellbeing and deliberative policy networks (4 April 2009). Institute for Ocean Management, Chennai, India.

Bebbington, A. 1999. Capitals and capabilities: a framework for analysing peasant viability, rural livelihoods and poverty. World Development 27(12):2021-2044. http://dx.doi.org/10.1016/S0305-750X (99)00104-7

Beck, T., and C. Nesmith. 2001. Building on poor people's capacities: the case of common property resources in India and West Africa. World Development 29(1):119-133. http://dx.doi. org/10.1016/S0305-750X(00)00089-9

Begossi, A. 2010. O manejo da pesca artesanal. Pages 179-234 in A. Begossi, P. F. M. Lopes, L. E. C. Oliveira, and H. Nakano, editors. Ecologia de pescadores da Baía da Ilha Grande. Rima, São Carlos, Brasil.

Begossi, A., A. Leme, C. S. Seixas, F. de Castro, J. Pezzuti, N. Hanazaki, N. Peroni, and R. A. M. Silvano. 2004. Ecologia de pescadores da Mata Atlântica e da Amazônia. Hucitec, São Paulo, Brasil.

Begossi, A., P. F. M. Lopes, L. E. C. Oliveira, and H. Nakano. 2010. Ecologia de pescadores da Baía da Ilha Grande. Rima, São Carlos, Brasil.

Béné, C. 2003. When fishery rhymes with poverty: a first step beyond the old paradigm on poverty in small-scale fisheries. World Development 31(6):949-975. http://dx.doi.org/10.1016/S0305-750X (03)00045-7

Béné, C. 2006. Small-scale fisheries: assessing their contribution to rural livelihoods in developing countries. Food and Agriculture Organization (FAO) Fisheries Circular No. 1008. FAO, Rome, Italy. 
Béné, C., L. Evans, D. Mills, S. Ovie, A. Raji, A. Tafida, A. Kodio, F. Sinaba, P. Morand, J. Lemoalle, and N. Andrew. 2011. Testing resilience thinking in a poverty context: experience from the Niger River basin. Global Environmental Change 21:1173-1184. http:// dx.doi.org/10.1016/j.gloenvcha.2011.07.002

Béné, C., and R. Friend. 2011. Poverty in small-scale inland fisheries: old issues, new analysis. Progress in Development Studies 11:119-144. http://dx.doi.org/10.1177/146499341001100203

Béné, C., G. Macfadyen, and E. H. Allison. 2007. Increasing the contribution of small scale fisheries to poverty alleviation and food security. Food and Agriculture Organization Fisheries Technical Paper No. 481. FAO, Rome, Italy.

Berkes, F. 2011. Restoring unity: the concept of marine socialecological systems. Pages 9-28 in R. Ommer, I. Perry, P. Cury, and K. Cochrane, editors. World fisheries: a social-ecological analysis. Blackwell, Chichester, West Sussex, UK. http://dx.doi. org/10.1002/9781444392241.ch2

Berkes, F. 2012. Implementing ecosystem-based management: evolution or revolution? Fish and Fisheries 13:465-476. http://dx. doi.org/10.1111/j.1467-2979.2011.00452.x

Berkes, F., J. Colding, and C. Folke, editors. 2003. Navigating social-ecological systems. Cambridge University Press, Cambridge, UK. http://dx.doi.org/10.1017/CBO9780511541957

Berkes, F., and C. Folke, editors. 1998. Linking social and ecological systems: management practices and social mechanisms for building resilience. Cambridge University Press, Cambridge, UK.

Berkes, F., R. Mahon, P. McConney, R. Pollnac, and R. Pomeroy, editors. 2001. Managing small-scale fisheries. International Development Research Centre, Ottawa, Ontario, Canada.

Blaikie, P. M. 1994. At risk: natural hazards, people's vulnerability, and disasters. Routledge, London, UK, and New York, USA.

Blount, B. G. 2007. Life on the water: a historical-cultural model of African American fishermen on the Georgia coast. NAPA Bulletin 28:109-122. http://dx.doi.org/10.1525/napa.2007.28.1.109

Chambers, R., and G. Conway. 1992. Sustainable rural livelihoods: practical concept for the 21st century. Institute of Development Studies Discussion Paper 296. Institute of Development Studies, Brighton, UK.

Christie, P. 2011. Creating space for interdisciplinary marine and ecological research: five dilemmas and suggested resolutions. Environmental Conservation 38(2):172-186. http://dx.doi.org/10.1017/ $\underline{\mathrm{S} 0376892911000129}$

Copes, P. 1989. Why are fishing incomes often low? A critical review of the conventional wisdom. Discussion paper 21/89-1. Institute of Fisheries Analysis, Simon Fraser University, Burnaby, British Columbia, Canada.

Coulthard, S. 2009. Ecosystem Services and Poverty Alleviation (ESPA) and the wellbeing of fishers. ESPA workshop 1 on building capacity for sustainable governance in South Asian fisheries: poverty, wellbeing and deliberative policy networks (4 April 2009). Institute for Ocean Management, Chennai, India.
Dale, V. H., S. Brown, R. A. Haeuber, N. T. Hobbs, and N. Huntly. 2000. Ecological principles and guidelines for managing the use of land. Ecological Applications 107:639-670.

Davidson, D. J. 2010. The applicability of the concept of resilience to social systems: some sources of optimism and nagging doubts. Society and Natural Resources 23:1135-1149. http://dx.doi. org/10.1080/08941921003652940

Department for International Development (DFID). 2005. Reducing poverty by tackling social exclusion: a DFID policy paper. DFID, London, UK.

Folke, C., T. Hahn, P. Olsson, and J. Norberg. 2005. Adaptive governance of social-ecological systems. Annual Review of Environment and Resources 30:441-473. http://dx.doi.org/10.1146/ annurev.energy.30.050504.144511

Forsyth, T. 2003. Critical political ecology: the politics of environmental science. Routledge, London, UK.

Gordon, S. H. 1954. The economic theory of a common property resources: the fishery. Journal of Political Economy 62:124-142. http://dx.doi.org/10.1086/257497

Greenberg, J. B., and T. K. Park. 1994. Political ecology. Journal of Political Ecology 1:1-12.

Gunderson, L. H., and C. S. Holling, editors. 2002. Panarchy: understanding transformations in human and natural systems. Island Press, Washington, D. C., USA.

Gupta, C. 2007. Bonded bodies: coastal fisherfolk, everyday migrations and national anxieties in India and Sri Lanka. Cultural Dynamics 19:237-255. http://dx.doi.org/10.1177/0921374007080293

Hanazaki, N., F. Berkes, C. S. Seixas, and N. Peroni. 2013. Livelihood diversity, food security and resilience among the Caiçara of coastal Brazil. Human Ecology 41:152-164. http://dx. doi.org/10.1007/s10745-012-9553-9

Hapke, H. M., and D. Ayyankeril. 2004. Gender, the worklife course, and livelihood strategies in a South Indian fish market. Gender, Place and Culture 11:229-256. http://dx.doi. org/10.1080/0966369042000218473

Instituto Brasileiro de Geografia e Estatística (IBGE). 2013. Censo demográfico 2010. [online] URL: cidades.ibge.gov.br/xtras/ perfil.php?lang $=\& \operatorname{codmun}=330380 \&$ search $=$ rio-de-janeiro|paraty $\mid$ infograficos:-informacoes-completas

Johnson, D. S. 2006. Category, narrative, and value in the governance of small-scale fisheries. Marine Policy 30:747-756. http://dx.doi.org/10.1016/j.marpol.2006.01.002

Johnson, D. S., M. Bavinck, and J. Veitayaki. 2005. Fish capture. Pages 71-91 in J. Kooiman, M. Bavinck, S. Jentoft, and R. Pullin, editors. Fish for life: interactive governance for fisheries. University of Amsterdam Press, Amsterdam, Netherlands.

Kates, R., W. C. Clark, R. Corell, J. M. Hall, C. C. Jaeger, I. Lowe, J. J. McCarthy, H. J. Schellnhuber, B. Bolin, N. M. Dickson, S. Faucheux, G. C. Gallopin, A. Grübler, B. Huntley, J. Jäger, N. S. Jodha, R. E. Kasperson, A. Mabogunje, P. Matson, H. Mooney, B. Moore, III, T. O'Riordan, and U. Svedin. 2001. Sustainability science. Science 292:641-642. http://dx.doi.org/10.1126/science.1059386 
Khan, A. S., and B. Neis. 2010. The rebuilding imperative in fisheries: clumsy solution for a wicked problem? Progress in Oceanography 87:347-356. http://dx.doi.org/10.1016/j.pocean.2010.09.012

Kurien, J. 1992. Ruining the commons and responses of the commoners: coastal overfishing and fishermen's actions in Kerala state, India. Pages 221-258 in D. Ghai, and J. Vivian, editors. Grassroots environmental action: people's participation in sustainable development. Routledge, London, UK.

Kurien, J. 1996. Towards a new agenda for sustainable small-scale fisheries development. South Indian Federation of Fishermen Societies, Trivandrum, Kerala, India.

Laderchi, C. R. 2000. The monetary approach to poverty: a survey of concepts and methods. QEH Working Paper Series No. 58. University of Oxford, London, UK.

Laderchi, C. R., R. Saith, and F. Stewart. 2003. Does it matter that we do not agree on the definition of poverty? A comparison of four approaches. Oxford Development Studies 31(3):243-274. http://dx.doi.org/10.1080/1360081032000111698

Leach, M., R. Mearns, and I. Scoones. 1999. Environmental entitlements: dynamics and institutions in community-based natural resource management. World Development 27:225-247. http://dx.doi.org/10.1016/S0305-750X(98)00141-7

Liu, J., T. Dietz, S. R. Carpenter, C. Folke, M. Alberti, C. L. Redman, S. H. Schneider, E. Ostrom, A. N. Pell, J. Lubchenco, W. W. Taylor, Z. Ouyang, P. Deadman, T. Kratz, and W. Provencher. 2007. Complexity of coupled human and natural systems. Science 317:1513-1516. http://dx.doi.org/10.1126/ science. 1144004

Lopes, P. F. 2010. O pescador artesanal da Baía da Ilha Grande. Pages 15-72 in A. Begossi, P. F. M. Lopes, L. E. C. Oliveira, and H. Nakano, editors. Ecologia de pescadores da Baía da Ilha Grande. Rima, São Carlos, Brasil.

Lowe, C. 2000. Global markets, local injustice in Southeast Asian seas: the live fish trade and local fishers in the Togean Islands of Sulawesi. Pages 234-258 in C. Zerner, editor. People, plants, and justice: the politics of nature conservation. Columbia University Press, New York, USA.

Ludwig, D., M. Mangel, and B. Haddad. 2001. Ecology, conservation, and public policy. Annual Review of Ecology and Systematics 32:481-517. http://dx.doi.org/10.1146/annurev. ecolsys.32.081501.114116

Mahon, R., P. McConney, and R. N. Roy. 2008. Governing fisheries as complex adaptive systems. Marine Policy 32:104-112. http://dx.doi.org/10.1016/j.marpol.2007.04.011

Marschke, M. J., and F. Berkes. 2006. Exploring strategies that build livelihood resilience: a case from Cambodia. Ecology and Society 11(1):42. [online] URL: http://www.ecologyandsociety. org/vol11/iss1/art42/

McGoodwin, J. W. 2001. Understanding the cultures of fishing communities: a key to fisheries management and food security. FAO Fisheries Technical Paper 401. Food and Agriculture Organization, Rome, Italy.
McGregor, A. 2008. Well-being, poverty and conflict. Briefing Paper 1/08. ESRC Research Group on Wellbeing in Developing Countries, University of Bath, Bath, UK.

Mearns, R. 1996. Environmental entitlements: pastoral natural resource management in Mongolia. Cahiers de Sciences Humaines 32:105-131.

Metzger, J. P. 2009. Conservation issues in the Brazilian Atlantic forest. Biological Conservation 142(6):1138-1140.

Millennium Ecosystem Assessment (MEA). 2005. Ecosystems and human well-being: general synthesis. Island Press, Chicago, Illinois, USA. [online] URL: http://www.millenniumassessment. org/documents/document.356.aspx.pdf

Miller, K., T. Charles, M. Barange, K. Brander, V. F. Gallucci, M. A. Gasalla, A. Khan, G. Munro, R. Murtugudde, R. E. Ommer, and R. I. Perry. 2010. Climate change, uncertainty, and resilient fisheries: institutional responses through integrative science. Progress in Oceanography 87:338-346. http://dx.doi.org/10.1016/ j.pocean.2010.09.014

Moreno, I. B., M. Tavares, D. Danilewicz, P. H. Ott, and R. Machado. 2009. Descrição da pesca costeira de média escala no litoral norte do Rio Grande do sul: comunidades pesqueiras de Imbé/Tramandaí e Passo de Torres/Torres. Boletim do Instituto de Pesca 35(1):129-140.

Narayan, D., R. Chambers, M. K. Shah, and P. Petesch. 2000a. Crying out for change: voices of the poor. World Bank Publication. Oxford University Press, New York, USA. http://dx.doi. org/10.1596/0-1952-1602-4

Narayan, D., R. Patel, K. Schafft, A. Rademacher, and S. KochSchulte. 2000b. Can anyone hear us?: voices of the poor. World Bank Publication. Oxford University Press, New York, USA. http://dx.doi.org/10.1596/0-1952-1601-6

Nayak, P. K. 2011. Change and marginalization: livelihoods, commons institutions and environmental justice in Chilika Lagoon, India. Dissertation. University of Manitoba, Winnipeg, Manitoba, Canada. [online] URL: http://mspace.lib.umanitoba. ca/handle/1993/5032

Nayak, P. K. 2014. The Chilika Lagoon social-ecological system: an historical analysis. Ecology and Society 19(1)1. http://dx.doi. org/10.5751/ES-05978-190101

Nayak, P. K., and F. Berkes. 2010. Whose marginalization? Politics around environmental injustices in India's Chilika Lagoon. Local Environment 15(6):553-567. http://dx.doi. org/10.1080/13549839.2010.487527

Nayak, P. K., and F. Berkes. 2011. Commonisation and decommonisation: understanding the processes of change in Chilika Lagoon, India. Conservation and Society 9:132-145. http://dx.doi.org/10.4103/0972-4923.83723

Nayak, P. K., and F. Berkes. 2012. Linking global drivers with local and regional change: a social-ecological system approach in Chilika Lagoon, Bay of Bengal. Regional Environmental Change. [online] URL: $\underline{\text { http://dx.doi.org/10.1007/s10113-012-0369-3 }}$ 
Neis, B., M. Binkley, S. Gerrard, and M. Maneschy. 2005. Changing tides: gender, fisheries and globalisation. Fernwood, Halifax, Nova Scotia, Canada.

Neumann, R. P. 2005. Making political ecology. Hodder Arnold, London, UK.

Oliveira, L. E. C. 2010. A percepção da conservação da Baía da Ilha Grande. Pages 235-286 in A. Begossi, P. F. M. Lopes, L. E. C. Oliveira, and H. Nakano, editors. Ecologia de pescadores da Baía da Ilha Grande. Rima, São Carlos, Brazil.

Ommer, R. E. 2007. Coasts under stress: restructuring and socialecological health. McGill-Queen's University Press, Montreal and Kingston, Canada.

Ommer, R., I. Perry, P. Cury, K. Cochran, editors. 2011. World fisheries: a social-ecological analysis. Blackwell, Chichester, West Sussex, UK. http://dx.doi.org/10.1002/9781444392241

Power, N. 2005. What do they call a fisherman? Men, gender, and restructuring in the Newfoundland fishery. ISER Books, St John's, Newfoundland and Labrador, Canada.

Ravallion, M. 1998. Poverty lines in theory and practice. LSMS Working Paper 133. The World Bank, Washington, D.C., USA. http://dx.doi.org/10.1596/0-8213-4226-6

Robbins, P. 2004. Political ecology: a critical introduction. Blackwell, Oxford, UK.

Robson, J. P., and P. K. Nayak. 2010. Rural out-migration and resource dependent communities: lessons from Mexico and India. Population and Environment 32:263-284. http://dx.doi.org/10.1007/ $\underline{\text { s11111-010-0121-1 }}$

Sachs, J. 2005. The end of poverty: economic possibilities for our time. Penguin, New York, New York, USA.

Scoones, I. 1998. Sustainable rural livelihoods: a framework for analysis. IDS Working Paper 72. Institute of Development Studies, Brighton, UK.

Sen, A. 1981. Poverty and famines: an essay on entitlement and deprivation. Clarendon, Oxford, UK.

Sen, A. K. 1999. Development as freedom. Oxford University Press, Oxford, UK.

Steinberg, P. F. 2009. Institutional resilience amid political change: the case of biodiversity conservation. Global Environmental Politics 9(3):61-81. http://dx.doi.org/10.1162/ glep.2009.9.3.61

Trimble, M., and D. Johnson. 2013. Artisanal fishing as an undesirable way of life? The implications for governance of fishers' wellbeing aspirations in coastal Uruguay and southeastern Brazil. Marine Policy 37:37-44. http://dx.doi. org/10.1016/j.marpol.2012.04.002

Walker, B., C. S. Holling, S. R. Carpenter, and A. Kinzig. 2004. Resilience, adaptability and transformability in social-ecological systems. Ecology and Society 9(2):5. [online] URL: http://www. ecologyandsociety.org/vol9/iss $2 /$ art5

Waltner-Toews, D., and J. Kay. 2005. The evolution of an ecosystem approach: the diamond schematic and an adaptive methodology for ecosystem sustainability and health. Ecology and Society 10(1):38. [online] URL: http://www.ecologyandsociety. org/vol10/iss1/art38/

Weeratunge, N., C. Béné, R. Siriwardane, A. Charles, D. Johnson, E. H. Allison, P. K. Nayak, and M. Badjeck. 2013. Small-scale fisheries through the wellbeing lens. Fish and Fisheries. [online] URL: http://dx.doi.org/10.1111/faf.12016

White, S., and M. Ellison. 2007. Well-being, livelihoods and resources in social practice. Pages 157-175 in I. Gough, and J. A. McGregor, editors. Well-being in developing countries: from theory to research. Cambridge University Press, Cambridge, UK.

Zerner, C., editor. 2000. People, plants, and justice: the politics of nature conservation. Columbia University Press, New York, USA. 